\title{
Research on College Computer Teaching Reform based on MOOC
}

\author{
Mengqing Feng 1,2,a
}

${ }^{1}$ School of Information Engineering, Zhengzhou University of Industrial Technology, Zhengzhou Henan 451150, PR China

${ }^{2}$ Machine learning and Data researching Institute, Zhengzhou University of Industrial Technology, Zhengzhou Henan 451150, PR China

a903901419@qq.com

Keywords: MOOC; Colleges and universities; Computer teaching; The teaching reform

\begin{abstract}
In today's era of MOOC there has a great impact on education at universities, have the characteristics of large, open, online MOOC has become an important means of teaching reform of colleges and universities. MOOC is suitable for the teaching of college computer course, with the help of a MOOC brought about by the new concept and new model, using the most advanced information technology for the majority of university computer teaching reform, provides the most effective support, to promote the development and reform of university teaching computer courses. The author mainly introduces the relevant concepts of MOOC and the main differences between traditional teaching mode and MOOC in modern environment, and puts forward the measures of college computer teaching reform under the background of MOOC.
\end{abstract}

\section{Introduction}

MOOC (Massive Open Online Course, Massive Open Online courses) originated in 2007, the state of Utah state university professor David Wiley based on Wiki to create a network Open courses "type to the Open Education (INST 7150)", in 2008, the Canadian Dave Cormier and Bryan Alexander, put forward the term MOOC[1], subsequently, the Canadian scholar George Siemens and Stephen Downes MOOC concept design the first real MOOC courses: Connectivism and Connective Knowledge Online Course (CCK08).In 2011, Stanford university tentatively released professor Andrew Ng's Machine Learning course online, and more than 100,000 students from all over the world registered for the course. In February 2012, Sebastian Thrun, a computer professor at Stanford university, and his colleagues David Stavens and Mike Sokolsky co-founded Udacity, a for-profit MOOC. In April 2012, Stanford university professors Daphne Koller and Andrew Ng founded MOOC for-profit Coursera. In May 2012, the Massachusetts institute of technology (MIT) and Harvard University created the nonprofit edX. Coursera, Udacity and edX are three typical MOOC platforms in the United States. Foreign universities such as Princeton, the university of Michigan, the university of Pennsylvania and the university of Washington have launched moocs.In 2012, the New York times called it "the first year of MOOC.

In recent years, MOOC (Massive Oprn Online Course) has set off an extremely important reform in the social higher education[2-6]. Wikipedia MOOC is defined as: a large open online course is a general crowd specifically for online courses, the way people in peacetime can through the network for online courses of study. Moocs are the latest development trend of remote education, which is formed by the form of open education resources. Actually, online education is also not what new things, just before the MOOC appear, part of the company as well as the school has tried such early education, but did not get good results. MOOC appearance can let everyone can at any time, any place to learn or use a variety of equipment, this way can make people to be able to study at Harvard University, Yale university courses such as the world's top colleges and universities. The emergence of moocs is not only the change of teaching methods, but also the reform of education concept and talent cultivation. 


\section{Comparison between Traditional Teaching Mode and MOOC}

The characteristics of the traditional teaching mode is in a fixed location, fixed time in the classroom teaching activities, but MOOC is different, its without any limitation on the time and place, and save the cost of education. Traditional teaching take passive teaching model, in the classroom teaching main would transmit the knowledge to students, teachers and students to passively accept knowledge, taught by the information, the same rate, ignoring the students learning ability as well as between their respective basis is different, this is very unfavorable to students themselves personalized learning. But MOOC is different, it can let students can choose at any time to watch the video or do exercise, also provides a good learning experience, students to participate in, comments or feedback, for the purpose of students comprehensive knowledge. MOOC characteristics can be large-scale open online education, it USES the information technology and network technology to the world with very high quality education resources, and the public basic application is free of charge. The effective combination between moocs and the current education can make education internationalized and truly reflect the fairness of education. MOOC, of course, also has its limits, although MOOC discussion and evaluation function, but due to the number of students, the interaction between teachers and students has been curbed, so the MOOC fit in with the independent ability strong students.

\section{The Measures of College Computer Teaching Reform under the Background of MOOC}

Moocs have obvious advantages over traditional teaching models, but they are not enough. The reform of computer course teaching in colleges and universities should use MOOC's advantages effectively to improve the teaching quality of university computers.

Effective Design and Use of Flipped Classroom. Usually in computer course of traditional teaching pattern in colleges and universities teachers as the main body, teacher knowledge in the teaching material content in the computer class, the students are listening to the teacher in class, after class to complete the relevant work arrangement by teachers. They turn over the classroom on the contrary, it take the student as the main body and the extracurricular autonomous learning, between teachers and students in the classroom can effective communication and interaction, to answer for the students, also can through the mutual discussion to help students get more harvest. In the course of introducing moocs into the teaching of computer courses in universities, the design of the course focuses on how to design flipped classroom. Before assigning students to study before class, they need to design the relevant homework before class. Before class, students can arrange the time to watch MOOC related teaching video. In order to enable students to effectively complete the study task of self-study, it is quite important for teachers to prepare homework before class. Teachers can ask questions based on the content of MOOC video, and ask students to answer questions, or ask students to ask questions. In addition, in college computer classes, teachers can organize or guide students to participate in the problems and discussions so that students can consolidate and verify the results of the autonomous learning period. Teachers also need to actively communicate with students and interaction, thus to personalized guidance of students, understand students' progress, can timely solve students doubts, make the students master more knowledge. Students can also complete the teacher the assignment or on the MOOC discussion, evaluation and assessment, and teachers can in MOOC, correcting students' homework, exchange and interaction with students, for further guidance.

Pre-class video learning is the basic knowledge preparation stage of flipped classroom training[7-10]. Video sources mainly include: teacher's own recording, MOOC platform or network resources, etc. First of all, the teacher has the selective arrangement of students to register and watch MOOC micro-video, and conduct training and test. The learning process is the same as that of MOOC video. To find in a MOOC course knowledge of video, mainly by the classroom teachers homemade micro video and uploaded to flip class network teaching platform, students according to learning tasks assigned by the teacher, to meet the needs of individual self-paced, rhythm, speed, and autonomous learning. Teacher homemade video, in the knowledge lecture before can design 
some questions, lets the student in which problems with the watch and find out, at the end of each interpretation, students complete assigned by the teacher practice questions, the test result through the network system instant feedback to students, students will be a lot of questions brought into the classroom to turn or through classroom network platform to teachers of proprietary BBS or weibo, micro letter, QQ group, such as social networking tools to communicate with teachers. Teachers homemade micro video regardless of the length, each video taught only a general knowledge and closely around the knowledge points, its aim is to strive to let the student in the video length of time, a comprehensive grasp video taught knowledge. The advantages are as follows: first, to make the knowledge more "compact" in the content, in accordance with the information processing group block strategy principle, to reduce the student memory burden; The ideological unity of the two is in form and Integrable Ware, teachers can accumulate a combination terrace in on-demand combination product, students are free to choose, dynamic combination teaching video, can meet the needs of personalized learning, can also expands the study scope; Three is a short video is more likely to attract the students attention, because before they are about to run out of a learning attention, knowledge have learned, students can make full use of fragmented time and learn the knowledge of fragmentation.

The Coupling of MOOC Resources with Flipped Classroom. In addition to providing traditional course materials such as video, reading and questions, moocs also set up a network interactive community. Flipped classroom is a mode of moocs, which have high identity, complementarity and coupling.

First, the high quality of MOOC resource design. Moocs are based on the course teaching process completed by the elite universities, and have a complete curriculum structure, such as course objectives, coordinators, topics, time arrangement, homework, etc. General course content by school teacher lecture, the micro video, tests, assignments, and the simulation results of design and development and adjustment are done by professional team, can well guarantee the quality of the design and manufacture of the teaching resources, and the quality of "elite + + class name" teacher resources is just flip the classroom students learning and in-class training required before class.

Second, the convenience of the use of MOOC resources. MOOC is a kind of free and open form of education, curriculum resources and information to all open and spread through the network, learners without number, the limitation of time, place and tools, the identity authentication and the authority of the courses and the function of the registration system is very simple. Student registration later can according to individual need to set the learning schedule, choose their own habits of communication tools such as wikis, blogs, social networking sites such as interaction learning. To not be able to timely in the course of real-time discussions, can watch the video or record by later to catch up. MOOC openness and personalized learning environment, easy to be used in turn classroom self-study before class, students are easy to be teachers incorporate as important material flip class in-class activities.

Thirdly, the interactivity of MOOC platform functions. MOOC platform provides an interactive training and machine automatic rating (Auto - grade) and student tracking management, and other functions, these functions can be used to turn the classroom, convenient student class training and immediate feedback, and convenient teachers undertake to the student management, timely grasp the students' learning dynamic, targeted organization class activities.

Fourth, the generative and constructive nature of MOOC content. MOOC is a generative course with dynamic convergence, mixing, transfer, and promoting sharing (Downes, etc.).Through the issue of topics and activities, teachers initially provide only a small amount of learning materials as the starting point for students' learning resources and knowledge inquiry. Students participate in the discussion topics, activities, thinking and communication, through the "path to look for" and "meaning construction" to construct their own learning and knowledge network, share new resources in the process of communication, new ideas, new ideas, through thinking collisions generate new knowledge, new content, became the center of learning and interaction. Flip the classroom before class online communication, problem of classroom discussion activities also have 
a generative and constructive, not only can broaden the knowledge field, provide students with endless learning content, and can improve the ability of students to explore new areas and new knowledge.

Effective Development of MOOC. The design of moocs is the most critical part of college computer courses in the application of moocs. Currently there are a lot of countries have all has launched its own MOOC platform, including Coursera (free large open online course project), Udacity (for-profit online education institutions) and edx (massive open online course platform) is called the world three big MOCC platform. Tsinghua university online is regarded as the largest MOCC platform in China. In computer teaching in colleges and universities teachers can according to the existent MOOC to fully effective arrangement of courses, of course, if the college computer course teachers can effectively develop their own MOCC is better. Develop lecture video and practice as the core learning resources. The process of explaining the content knowledge in each unit of the computer course is made into micro-video. Knowledge of micro video content are interesting enough, to attract the attention of students, to try to shoot during filming the video it is relatively simple, if the video time too long can cause the students' boredom, fatigue. During the filming and production of micro video teachers can arrange related with textbooks during video playback of exercises in the video to let the students answer, after waiting for students to answer continue to watch the video, so reasonable arrangements can effectively focus the attention of students, enhance the students' thinking ability, at the same time to deepen understanding of the content of the knowledge they learned in class.

\section{Conclusion}

At present, both domestic and foreign theoretical research and analysis of moocs are gradually increasing, and the emergence of moocs has brought innovation to the teaching reform of university computers. Moocs have emerging technologies that enable teachers, students and platforms to communicate and interact with each other anytime, anywhere, and to provide free quality resources. The emergence and application of moocs is not only the breakthrough and reform of the open teaching mode of the Internet, but also the reform of computer course teaching in colleges and universities. As the important force in the computer teaching reform, the general computer education workers need to constantly absorbing more MOOC at the forefront of the technology, the concept, using the most advanced information technology for the majority of university computer teaching reform to provide the most effective support, to promote the development and reform of university teaching computer courses.

\section{References}

[1] Mcauley A, Stewart B, Cormier D, et al. The MOOC Model for Digital Practice[J]. 2010.

[2] Y I Liu. MOOC Spurs Higher Education Reform[J]. China Today, 2014(3),P.50-52.

[3] Ya-Feng H E, Z M Cheng and C Y Zhu. MOOC: The Prelude of Higher Education Reform in Post-Industrial Society[J]. Adult Education, 2014.

[4] L I Qiang, School I and Financeamp S. The Reform of Education Structure Led by MOOC \& Cloud Computing Technology__ The Trend of Education Informationization Reform and Development in the Era of Big Data[J]. Journal of Shanxi Institute of Economic Management, 2017.

[5] Bady A. The MOOC Moment and the End of Reform.[J]. Liberal Education, 2013, 99(4),P.118-119.

[6] J Shen, M Ye, Y Wang, et al. Massive open online course (MOOC) in China: Status quo, opportunities, and challenges[C]// Global Engineering Education Conference. IEEE, 2016,P.1106-1108.

[7] Gavriel J. The flipped classroom[J]. Education for Primary Care, 2015, 26(6),P.424-425.

[8] Herreid C F, Schiller N A. Case Studies and the Flipped Classroom[J]. Journal of College Science Teaching, 2014, 42(5),P.62-66. 
[9] Enfield J. Looking at the Impact of the Flipped Classroom Model of Instruction on Undergraduate Multimedia Students at CSUN[J]. Techtrends, 2013, 57(6),P.14-27.

[10] Mclaughlin J E, Roth M T, Glatt D M, et al. The flipped classroom: a course redesign to foster learning and engagement in a health professions school.[J]. Academic Medicine Journal of the Association of American Medical Colleges, 2014, 89(2),P.236. 